\title{
English in the nursing degree: a pending subject
}

\author{
Rafaela Camacho-Bejarano ${ }^{1}$ \\ Ana Barquero-González ${ }^{2}$ \\ María Isabel Mariscal-Crespo ${ }^{2}$ \\ Dolores Merino-Navarro²
}

\begin{abstract}
Objective: The new competence profile of nursing professionals, scientific and medical development, the free circulation of health professionals worldwide, and the increasing social and cultural diversity requires that nurses have specific abilities in spoken and written English. The objective of this research is to describe the characteristics of the English language training required for a Bachelors of Nursing in Spain. Method: A descriptive cross-sectional observational study has been performed in forty-six Spanish universities that offer the Bachelor in nursing degree. Results: In line with the directives of the European Higher Education Area, all universities contemplate the mandatory credit of a second language emphasizing English, although there is considerable variability in the emphasis: $39.4 \%$ do not include any English subject, and of the remaining $60.6 \%$ who do include it, $60 \%$ considered it an elective subject, $32.5 \%$ basic education, and $7.5 \%$ mandatory. Conclusions: The English training has different characteristics in each university, which implies a different commitment from each center for this learning. This fact questions the adequacy of the education in relation to the new competence profile required by the European Higher Education Area, which may adversely affect future professional development.
\end{abstract}

Descriptors: Education, Nursing; Health Communication; Multilingualism.

\footnotetext{
${ }^{1}$ Doctoral Student, Departamento de Enfermería, Universidad de Huelva, Huelva, España.

2 PhD, Full Professor, Departamento de Enfermería, Universidad de Huelva, Huelva, España.
}

Corresponding Author:

Rafaela Camacho Bejarano

Universidad de Huelva. Facultad de Enfermería

Campus El Carmen

Av. Tres de marzo, s/n.

CEP: 21071, Huelva, España

E-mail: rafaela.camacho@denf.uhu.es 


\section{Introduction}

In the current reality, an unprecedented worldwide transformation is occurring in higher education. As reflected in the World Declaration on Higher Education in the XXI century by UNESCO(1), higher education and research are fundamental to the development of individuals, communities, and nations, which are the engine of the global knowledge society.

Thus the Convergence Process among National Higher Education Systems of European Universities arises, whose primary goal is the creation of a single European Higher Education Area (EHEA). The purpose of this ambitious project is to increase the mobility and employment of graduates, ensuring international competitiveness and the quality of higher education. Within this process of change the Tunning Project for Latin America(2) has been designed in order to define the academic and professional profiles based on abilities and to achieve higher educational convergence in this environment.
In the European context, numerous initiatives have been developed to promote learning of a common language to facilitate the exchange of students and professionals. Among them, the Common European Framework of Reference for learning, teaching, and evaluation of languages, which is part of the language policy of the General Council of Europe, promotes an intensification of learning and the teaching of languages to facilitate greater mobility, more effective international communication, increased access to information, and improved industrial relations(3).

\section{Curriculum design of graduate nursing programs in Spain: English language education}

The National Agency for Quality Assessment and Accreditation (ANECA) developed in 2005 the basis for the formation process of the nursing degree in the White Paper of the Nursing Degree (el Libro Blanco del Grado en Enfermería) ${ }^{(4)}$, redefining job profiles and abilities ${ }^{(5-6)}$. The list of the most relevant abilities related to the learning of a second language is described in Figure 1.

\begin{tabular}{|c|l|}
\hline Code & \multicolumn{1}{|c|}{ General Competencies } \\
\hline CG7 & Knowledge of a second language \\
\hline CG11 & Information Management Skills (to search and to analyze) \\
\hline CG22 & Appreciation of diversity and multiculturalism \\
\hline CG23 & Ability to work in an international context \\
\hline CG24 & Knowledge of other cultures \\
\hline Code & \\
\hline CE 11 & Capacity to enforce clinical judgments to ensure that quality standards are achieved and the practice is based on evidence \\
\hline CE 23 & Relevant knowledge and ability to implement national and international policy \\
\hline
\end{tabular}

Source: White Paper of Nursing Degree ${ }^{(4)}$

Figure 1- Abilities related to learning a second language

In parallel, the new regulation of college graduate studies introduced access to Master and Doctoral programs in the Spanish university system, opening a complete educational development for nursing, which also emphasizes English training and mobility within the European Area(7-8). There are numerous studies that highlight the need to encourage training in English in both the clinical and teaching fields, as well as in the undergraduate and postgraduate researcher ${ }^{(9-11)}$.

Curricular strategies should be oriented towards including specific assignments that include clinical care application and that deepen the approach in the scientific and research field, with reference to the new competence profile and with the aim of optimizing the teaching-learning process $^{(12)}$.

\section{Competence Profile of Nursing Professionals}

Among the objectives of the nursing studies within the higher education framework, reform is intended to respond to the current complexity of the health services that increasingly require nurses to have expertise in the management of complex information, use of new technology, planning, implementing and evaluating care interventions, and promoting a practice based on scientific evidence.

This process is taking place in a similar manner within the Latin American context, where the growth potential of the nursing discipline requires the adaptation of the professional profile to new needs and demands of society, approaching the academic and professional 
reality ${ }^{(13)}$. The heterogeneity in nursing education in Latin America, as reported by several authors ${ }^{(13-16)}$ also reflects the need to unify criteria, especially those related to research and the use of scientific evidence. In this sense, and because of the common linguistic characteristics between Latin America and Spain, it is imperative to establish English language transmission mechanisms to enhance the full development of the nursing discipline.

\section{New horizons in the academic and scientific-research field}

In the scientific and academic fields, English is the common language and the implementation of English is essential for analyzing the most relevant results in research, and therefore, the incorporation of scientific evidence into practice. The International Council of Nurses (ICN) argues that the general care nurse must possess skills related to the design and evaluation of programs and research projects ${ }^{(17)}$.

Among the most notable difficulties for the full development of nursing research includes, among others, limitations in the use of the English language, essential for searching international databases and for the international dissemination of research, given that the scientific journals with the greatest impact are published in this language ${ }^{(8-9,18-19)}$. The new competencies related with research highlight the urgent need to base nursing practice on the results of scientific evidence and as key to its achievement, English proficiency(20).

\section{Socio-demographic and cultural changes}

The growing cultural diversity within our society requires that health care services and its professionals have the ability to respond to a very diverse population with significant language barriers, which make it difficult and even impossible for proper communication between users and professionals. The learning of languages in the health field is connected to the holistic person approach, including sociocultural aspects, which builds on the knowledge of other languages as the foundation of the communication process, to the cultural context of the person who identifies his set of values and beliefs(21-22).

\section{International mobility}

The importance of international mobility, one of the cornerstones of the EHEA, aims to promote the free movement of students and professionals from different fields. This international mobility in the field of nursing materializes from two perspectives: on one hand, the exchange of teachers and students through mobility programs and research visits, and on the other, the mobility of already skilled professionals who contemplate international projections as a new labor perspective, where English language proficiency plays a fundamental role(23).

These exchanges are for learning or perfecting a second language and to promote projects of cooperation and exchanges of experience in teaching and research. This reality, coupled with the restructuring of health systems in many countries, is causing a massive demand for healthcare professionals, which translates into new opportunities in the labor market.

\section{Objectives}

To describe English language training within the new study plans (SP) of the Bachelor of Nursing in Spain.

To determine its characteristics in relation to the number of courses, number of credits, structure, methodology, objectives, content, skills and assessment systems.

To assess the adequacy of English training according to the guidelines set by the EHEA.

\section{Method}

\section{Type of Study}

A descriptive, cross-sectional, observational study was conducted in forty-six Spanish universities that offered the Bachelor in Nursing degree to determine the importance of English training within the curriculum.

\section{Population and study setting}

Sixty-six centers from 46 Spanish universities were included. The characteristics of those included centers are detailed in Table 1.

Table 1- Spanish centers which impart the Nursing Degree

\begin{tabular}{|c|c|c|}
\hline Type of Center & Total Number & Centers included \\
\hline Centers owned by Public Universities & 46 & $46(100 \%)$ \\
\hline Centers attached to Public Universities & 40 & $12(30 \%)$ \\
\hline Centers of private universities - belonging to the church & 16 & $8(50 \%)$ \\
\hline Total & 102 & 66 \\
\hline
\end{tabular}

Source: National Registry of Universities (Registro Nacional de Universidades) ${ }^{(24)}$ 


\section{Instrument}

The instrument used was a spreadsheet that enabled the downloading of data, where the units of analysis that were evaluated in each SP of the universities were collected. The instrument consisted of four units or categories of analysis: profile of college access, English training in the Bachelor of Nursing (subject denomination, type and number of credits, content, goals, skills, methodology, and assessment systems), accreditation systems for foreign languages, and the existence of mobility programs.

The instrument design was accomplished through consensus among a group of experts in design and SP evaluation. The validation was performed using expert judgment in which a total of ten teachers from eight Spanish universities participated, with the following profiles: deans (4), department heads (2) and renowned professors with expertise in the development of SP (4). Data collection was conducted between April and June 2011, using the Nursing Degree study plan published by each university as the data source.

\section{Data Analysis}

Given the nature of the study, a quantitative analysis was performed, by calculating frequencies and percentages through the SPSS statistics program, v.18, and a qualitative analysis through which the designation of the subjects, the objectives, content and skills set were analyzed.

To protect the interests of each university, the centers have been listed, but without specific details about each one of them. The data has been described broadly, in line with the objectives of the study.

\section{Results}

\section{Access profiles to the title of Degree in Nursing}

The different Spanish universities agreed that the desirable requirement, which prospective degree students should meet, had English highlighted as a required transversal competence. Specifically, to access the Nursing Degree, all universities recommended having knowledge of a modern language, with particular emphasis on English, and therefore its importance is evident from the pre-university stage.

\section{English language training within the Nursing Degree}

The totality of the SP (100\%) explicitly recognized the need to encourage the use of English for future professionals in the fields of patient care, teaching, and research. However, there was a notable variability in the actual importance attributed by the various Spanish universities, with significant differences in the content, structure, and competencies established in the subject of health-related English, especially in relation to the number of credits, course type, and orientation.

\section{Name of the subject}

The name of the subjects was varied and responded to the focus of the content: English, Technical English, Health-related English, English for Nursing, Scientific English, Scientific English for Nursing, Professional English, English applied to Nursing, English for Health Science, Scientific English, Specific English, English for Health and Behavioral Sciences, English for Health Science: Nursing, Modern Language, International English and English for Health Professionals.

\section{Type and number of credits}

Of the 66 centers included in the study, the mean frequency of SP that did not include a specific English subject was $39.4 \%(n=26)$, with a $60.6 \%(n=40)$ of the SP that did include. Among the centers that offered a course in English, 60\% $(n=24)$ considered it to be an elective, $32.5 \%(n=13)$ included it in basic training, and $7.5 \%(n=3)$ considered it mandatory, as detailed in Figure 2.

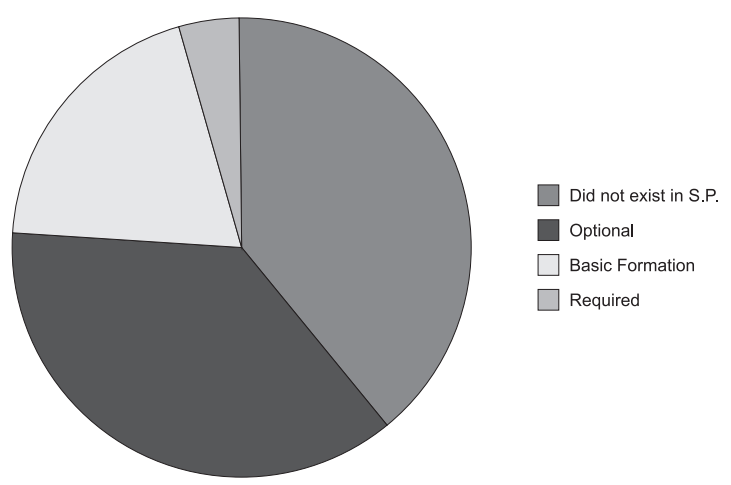

Figure 2 - English Training in the SP of the Nursing Degree

The credits for English training ranged from 0 to 18 ECTS, being conditioned by the nature of the subject. The core, mandatory, and optional English subjects had between 3 to 6 credits, according to each SP. Of all the universities included, only one offered 18 ECTS in English training from a dual perspective, as a core subject 
(6 ECTS) in first year, and as two additional electives (12 ECTS) over four years. The second university, with the largest amount in credit numbers, offered 12 ECTS divided into two elective subjects. In the rest, the predominant value was 6 ECTS, optionally, with an average credit at universities with specific training in English of 6.3 ECTS. The mean of credits including all centers stood at 2.5 ECTS.

\section{Content}

The majority of the subjects were oriented to the acquisition of a basic level of English, but all of them also included specific health issues content. This content varied from fundamental clinical concepts to application-oriented content of the English language in the scientific-research field (bibliographic searches, reporting and / or abstracts in English, interpretation of research results, etc.), although in a minor amount. In some subjects, aspects of career counseling in other countries (developing a resume, techniques for international job searches, preparing for job interviews, etc.) were specifically considered, although the content was not widely developed.

\section{Objectives}

The common goals established for English learning in the nursing degree can be summarized as the following: analyze, synthesize, and understand scientific and technical literature related to health sciences in English; find general and scientific-technical information in English; understand and use specific terminology related to the occupation; maintain a professional level of conversation in English at a basic level; write a simple report and/or make a simple presentation in English; know, appreciate, and respect the customs and traditions of English-speaking cultures, and integrate into an international team.

\section{Abilities}

The general competencies proposed within the English subjects in the nursing degree can be summarized as:

Ability to communicate verbally and in written English, according to the needs of the field of study and the demands of the academic and professional environment.

Information management skills (ability to retrieve and analyze information from various sources).

Ability to work in an international context.

Knowledge and ability to speak, understand, and write a second language.

Specifically, each university proposed more concrete competencies under the general orientation of English language training: clinical care, scientific research, teaching, management or guidance towards working abroad, which included:

Being able to maintain adequate communication in English with patients/users and other professionals.

Ability to summarize and translate text from English to Spanish and vice-versa, in areas related to health sciences.

Basing nursing interventions on scientific evidence.

Knowing the health information systems at national and international levels as well as showing the proper management of them.

Applying technology and information and communication systems.

Promoting employment seeking skills and entrepreneurial capacity.

\section{Methodology and assessment systems}

These areas exhibited similar characteristics, highlighting the continuous monitoring during the teaching-learning process and the use of resources to promote interaction between teachers and students, with an emphasis on progressive self-learning. The most often used assessment systems were portfolios as evidence of learning, combined with written and oral tests.

\section{System of accreditation in a second language}

All the SP of the Nursing Degree manifested the mandatory accreditation of a second language, assessing English as one of the indispensable languages, even in universities which did not offer any English subject.

Second language accreditation systems varied slightly from one university to another, but in general, the guidelines set by the Common European Framework for Language were followed,_which determined that the acquisition of B1 level certifies an acceptable level of language proficiency in those places where it was used (work, study, and leisure) and to standardize international requirements. In this sense, and despite the fact that the Common Framework of reference for languages established general guidelines, accreditation of a second language in the degree courses varied according to the Autonomous Community and the University ${ }^{(1,23)}$. For this, different alternatives have been established according to autonomous legislation, so that some universities offered a unique path (accreditation through an objective 
test of level, establishing different thresholds: B1 or B2) while others provided different options to suit the preferences of the students: taking and passing specific subjects established in the Study Plans, acceptance of official language certificates submitted by students, etc. Therefore, in order to obtain a Bachelor's in Nursing, it will be necessary, despite passing all subjects in the study plan, to demonstrate proficiency in English or another foreign language ${ }^{(2)}$.

\section{Existence of mobility programs}

All universities had mobility programs for teachers and students through Erasmus or pre/postdoctoral research programs.

\section{Discussion}

There is little doubt that learning a second language is one of the cornerstones of the new EHEA, as evidenced by the documents in the framework of the Nursing Degree and numerous studies which recognized that proficiency in English is essential at the academic, clinical, and research level(1-2,4-9,12-20). However, this recognition reflected in the SP of the Degree in Nursing from different Spanish universities did not correspond to the academic weight accorded within the university curriculum.

There are, thus, discrepancies between the stated emphasis on the importance of training in English for Nursing professionals and the proposed content. Despite the recognition of English as a transversal subject, not all of the SP included specific subjects, and of those that did, a high percentage included it as optional, which translates to an enormous training amalgam, which does not guarantee a minimum level of English proficiency that, on the other hand, will be required for graduation.

The need for future nurses to possess abilities in English is explained but the appropriate training is not offered, neither in terms of number of credits, orientation, or competencies, nor is it in line with established accreditation systems for a second language. For this purpose, other training mechanisms should be enabled (through modern language services, related courses, etc.), which increase the variability in basic training in English and added workload for students, with consequent difficulties in terms of time, lack of specificity of content and assuming an additional economic cost.

The implementation of the B1 accreditation system in the majority of universities has a main advantage of standardizing requirements. However, it does not integrate specific content that would provide a greater practical application for future work performance, highlighting the discrepancy existing between the training, the professional interest of students, and the level of exigency required at the academic level.

Among the implications of not considering specific subjects, a possible increase in the degree of difficulty arises for the students to reconcile this training with their studies. The learning process of a second language is more logical and coherent if integrated in the SP in accordance with the transversal abilities required in other subjects (bibliographic searches in international databases, writing scientific papers, critical reading). These differences may adversely affect the motivation and interest of students towards learning English, as some studies describe ${ }^{(25)}$.

The results of this research are subject to the information obtained from each university. A representative sample of Spanish universities that offered the Nursing Degree was selected, including all public, and an estimated proportion of affiliated centers, given that most maintain the SP structure of the university of reference. In the case of the private centers, the limited access to data has conditioned their inclusion, and does not reflect the generality. In the absence of previous similar studies, the results could not be compared; it is assumed that it is a relatively unexplored subject, of great relevance to the future professional.

\section{Conclusion}

Although the EHEA emphasizes learning English as a second language, and it is considered a fundamental transversal competence for all students to receive new degrees, there is considerable variability in importance within the different course syllabi for the Nursing Degree from a quantitative and qualitative point of view. These differences could adversely affect the profile of the future nursing professionals, limiting their full potential in academic, clinical, and research level, especially from an international perspective. The fact that a significant number of universities did not include English or offer it as an elective, questions whether or not they are making a real commitment to the learning of English. Similarly, there is a significant imbalance between the level of competence required in mastering a second language in the new Nursing Degree (B1) and the training offered from the universities, proposing new 
training needs that are not being covered in a uniform manner. Thus, the need arises to reach consensus on English language formation within the Bachelor of Nursing, and to potentiate the educational opportunities available, integrated into the required accreditation system and with adequate guidance regarding the needs of students, and the new competency profiles within the national and international health care system, which serve to consolidate a true knowledge society without language differences as a barrier.

\section{References}

1. UNESCO. Declaración Mundial sobre la Educación Superior en el Siglo XXI: Visión y acción. UNESCO; 1998-2009. [acesso 18 out 2011] Available from: http:// unesdoc.unesco.org/images/0011/001163/116345s.pdf.

2. Narváez E. La Educación Superior en América Latina ante los desafíos de la globalización. Rev Venezolana Educ Educere 2005;9:29.

3. Ministerio de Educación, Cultura y Deporte (ES). Marco Común Europeo de referencia para las lenguas. Madrid: Ministerio de Educación, Cultura y Deporte; 2002.

4. Agencia Nacional de Evaluación de la Calidad y Acreditación (ANECA). Libro Blanco. Título de Grado de Enfermería; [acesso 12 jul 2011]. Available from: http:// www.aneca.es/

5. Palomino Moral PA, Frias Osuna A, Grande Gascón ML, Hernández Padilla ML, Del Pino Casado R. El Espacio Europeo de Educación Superior y las competencias enfermeras. Index Enferm. 2005;14(48-49):50-3.

6. Silva KN, de Sena RR. La educación en Enfermería: búsqueda de información crítica y reflexiva $y$ de competencias profesionales. Rev. Latino-Am. Enfermagem 2006;14(5):755-61.

7. RD $1393 / 2007$ (ES), de 29 de octubre por el que se establece la ordenación de las enseñanzas universitarias oficiales; [acesso 10 set 2011]. Available from: http://www.boe.es/boe/dias/2010/07/03/pdfs/ BOE-A-2010-10542.pdf

8. Martínez Riera J.R. Barreras e instrumentos facilitadores de la Enfermería basada en la evidencia. Enferm Clín. 2003;13(5):303-8.

9. Harrison L, Hernández A, Cianelli R, Rivera MS, Urrutia M. Competencias en investigación para diferentes niveles de formación de enfermeras: una perspectiva latinoamericana. Cienc Enferm. 2005;11(1):59-71.

10. Lora López P. Reflexiones sobre el Grado y Postgrado de Enfermería: la investigación en Enfermería. Index Enferm. 2008;17(2):85-6.
11. Sierra Figueredo $S$, Fernández Sacasas JA, Miralles Aguilera E, Pernas Gómez M, Diego Cobel JM. Las estrategias curriculares en la Educación Superior. Rev Educ Médica Superior 2009;23(3):96-104.

12. Manzo BF, Ribeiro HCTC, Brito MJM, Alves M. La enfermería en hospital en proceso de acreditación: su papel y las conse $\neg$ cuencias en el trabajo diario. Rev. Latino-Am. Enfermagem. [periódico na Internet]. ene.feb. 2011 [acesso 12 ago 2012];20(1):[08 pantallas]. Available from: http://www.scielo.br/pdf/rlae/v20n1/ es_20.pdf

13. Lanzoni GMM, Meirelles BHS. Liderazgo del enfermero: una revisión integradora de la literatura. Rev. Latino-Am. Enfermagem. [periódico na Internet]. mayo-jun. 2011 [acesso 24 set 2012];19(3):[09 pantallas]. Available from: http://www.scielo.br/pdf/rlae/v19n3/es_26.pdf 14. Manfredi M. El desarrollo de Enfermería en América Latina: una mirada estratégica. Rev. Latino-Am. Enfermagem. 1993;1(1):23-35.

15. De Sena RR, Coelho S. Educación en enfermería en América Latina: necesidades, tendencias y desafíos. Invest Educ Enferm. 2004;22(2):120-7.

16. Harrison L, Hernández AR, Cianelli R, Rivera M.S. Competencias en Investigación para diferentes niveles de formación de enfermeras: una perspectiva latinoamericana. Cienc Enferm. 2005;11(1):59-71.

17. Consejo Internacional de Enfermería. Declaración de posición: Invest en Enferm 1999 [acesso 14 set 2011] Available from: www.icn.ch/psresearch99sp.htm 18. Orellana Yañez A, Paravic Klijn T. Enfermería basada en evidencia. Barreras y estrategias para su implementación. Cienc Enferm. 2007;23(1):17-24.

19. Rassool GH. Writing for an international publication in nursing journals: a personal perspective (part 2). Rev. Latino-Am. Enfermagem. 2006;14(3):428-34.

20. Fuentelsaz-Gallego C, Navalpotro-Pascual S, Ruzafa Martínez M (2007) Competencias en investigación: propuesta de la Unidad de coordinación y desarrollo de la Investigación en Enfermería (Investén). Enferm Clín. 17:117-27.

21. Plaza del Pino FJ, Soriano Ayala E. Formación de los profesionales de Enfermería: cuidar en la sociedad multicultural del s. XXI. Index de Enferm. 2009;18:190-4. 22. Frank RA. Medical communication: non-native English speaking patients and native English speaking professionals. English Specific Purposes 2000;19:31-62. 23. Ruzafa Martínez M, Madrigal Torres M, Velandrino Nicolás A, López Iborra L. Satisfacción laboral de los profesionales de Enfermería que trabajan en hospitales ingleses. Gaceta Sanit. 2008;22:434-42. 
24. Registro Nacional de Universidades, Centros y Enseñanzas del Ministerio de Educación y Ciencia del año 2008. España: Ministerio de Educación y Ciencia; 2008.

25. Saravia E, Bernaus M. Motivación y actitudes para el aprendizaje de lenguas de dos colectivos de estudiantes universitarios: futuros maestros de lenguas extranjeras y futuros enfermeras y fisioterapeutas. Porta Linguarum. 2008; $10: 163-84$. 